\title{
Varieties of Code Used by a Mixed Culture Student
}

\section{Theodoron Fredrik}

English Department, Faculty of Letters, Petra Christian University, Siwalankerto 121-131, Surabaya 60236, INDONESIA

e-mail: theodfredrik29@gmail.com

\begin{abstract}
Codes or dialects are the most important factor in society to communicate every day. In a society, a person acquires and learns the particular code to get along with the community. It becomes interesting when a person can speak more than one code. The purpose of this study is about the varieties of code used by a person on several occasions with different people and codes/dialects. This study used qualitative approach. The results show that there were five codes that the subject used and the most frequent code spoken by the subject was Kupangnese. It can be concluded that the participants whom the subject talked to influenced the Kupangnese code to occur more.
\end{abstract}

Keywords: variety, code, mixed culture

\section{INTRODUCTION}

Codes/dialects are needed within communities for daily life communication. Each community in every province has its own code/dialect. In order to build a decent communication with other communities, the communicator needs to understand more than just a national language. There is a unique fact of being an Indonesian family, namely Indonesians are very much attached to their respective regional languages. Being a person who can speak more than one language and dialect will advantage the person in many ways, especially when the person wants to get along with the community. For example, people especially students from the eastern part of Indonesia studying in Java island. Students from East Nusa Tenggara, Ambon, or Papua usually can speak more than one language or dialect by acquiring the language or learning the language, which is very helpful to build communication in a particular community.

According to Holmes (2013), sociolinguistics is the study of the relationship between language and society (p. 1). Also, Coulmas (2005) states that a language displays its speakers' identity, and as the tool to identify the speakers when they speak some languages or codes (p. 171). As an example, it is very common among university students from outside Java when they move and study in Java, they must speak or learn more than one code. It becomes an interesting situation to analyze because it happens naturally within everyday life, and it shows how code or dialect is greatly influenced by social factors and dimensions. On the other hand, it also shows how Indonesians are very open and respect the differences in language diversity by showing enthusiasm to learn the local language. When students from outside Java face this situation, they are more aware and susceptible to language because they meet lots of people with different codes (language). The writer chose one person who lived in Papua for approximately 18 years and his parents are from Toraja and Manado as the subject of this study. The writer focused on the subject's varieties of languages and dialects. There are some codes or dialects that the writer expects such as Javanese, Ambonese, Kupangnese, and Papuan. There are some reasons why the writer chooses the student as the subject. First, because the subject is the type of person that is active to communicate with people that use different codes. Also, he has a mixed cultural background. He has the enthusiasm to try his best to switch his code into other codes. As an example, he usually switches the pronoun word "I" into sa or beta when he talks to Papuan or Ambonese and Kupangnese students. Second, when he speaks another code or dialect which is not 
Fredrik: "Varieties of Code Used by a Mixed Culture Student"

his mother tongue, people usually identify his speech or utterances as the native speaker, and he can pronounce every word or even dialect like the native speaker.

This article discusses five varieties of codes namely Indonesian, Kupangnese, Papuan, Javanese, and English. First of all, the Indonesian code is analyzed regarding KBBI from Badan Pengembangan Bahasa dan Perbukuan (2016), all the utterances in Indonesian code are considered as formal language if the words are written inside the KBBI, and the non-standard words that usually used among the Indonesian community are considered as informal Indonesian based on the explanation from KBBI, for example, the word gak is usually used widely in Indonesia to refer to the word tidak or no, but it is in a non-standard form of Indonesia, another example is the word gitu and the standard form based on KBBI is begitu.

For the Kupang dialect, it is stated in the journal written by Jacob \& Grimes (2006), that while Indonesian is the official mode of communication of the government in Kupang, even in government offices it is limited to formal speeches and written communication. Kupang dialect has no status classification among its speakers but it is classified as an intimate dialect for the people from Kupang, because it already becomes the dialect of brotherhood. Some Papuan dialect words have the same meaning and pronunciation with the Kupang dialect, so the context of the conversation also plays an important role in the analysis to decide whether this is a Kupang or Papuan dialect. The main book reference that helps the writer to analyze the Papuan code is a book called "A grammar of Papuan Malay" by Kluge (2017), it is cited in the book that the findings of the 2007 survey indicate that Papuans associate Papuan Malay with intimacy and informality, while they associate Indonesian with social distance and formality (Scott et al. 2008). There are also some examples in the book using Papuan dialect, for example, they usually use the word $s a$ to refers to the pronoun I or me and ko to refers to the pronoun you, here are the examples: sa pegang sa pu parang sa punya jubi, the sentence means I took my short machete, my bow and arrows, and ko sendiri ka? Means are you alone or (not).

The next code is the Javanese code, which has the levels of formal and informal forms of language within its speaker. Poedjosoedarma (1979 in Hidayati, 2017) divides the code of Javanese into three levels, which are; (1) tingkat tutur krama, (2) tingkat tutur madya, and (3) tingkat tutur ngoko. There is also a Bahasa Jawa Bahasa Indonesia I dictionary arranged by Nardiati, Suwadji, Mp., Pardi, \& Suwatno (1993) that is also useful for the writer to find out the meaning of words in Javanese code. Other than that, as cited in the website SOLO.co.id, it explains the different levels of the word "Thank You". Matur nuwun is considered as the krama ngoko level, which is usually used by young people to the respected people. Meanwhile, matur suwun is incorrect for some people but still, the word is widely used among young people in the level of ngoko or daily language.

Last of all is the English code, to classify the words considered into English code, the writer used the dictionary of Oxford Advanced Learner's Dictionary, written by Hornby (2010) to find out and prove the English words. There are some words spoken by the subject such as print, handphone, transfer, owner, founder, etc.

\section{METHODOLOGY}

To get accurate data for this research, the writer joined the subject on several conversations and occasions with different people. The writer observed until acquiring enough data about the codes used by the subject in his interactions with the people from different areas and occasions, such as his friends from college or neighborhood, and his co-workers in his office. The observation lasted for 4 days. After that, the writer classified the data based on the day of observation. The writer took the data by observing the subject on 21 November 2019 at around the campus area for data 1, 09 February 2020 and 16 February 2020 in the subject's internship office 
for data 2 and 3, and 18 March 2020 in the subject's boarding house for data 4. Based on those conversations, utterances that were considered as code-switching were classified to see the codes used by the subject.

\section{FINDINGS AND DISCUSSION}

The subject's native code/dialect is Papuan because he was born in Toraja but he grew up in Papua. He speaks five codes/dialects in total: Kupangnese, Papuan, Indonesian, Javanese, and English codes. There are examples of those codes in the extract below to show that the subject could speak and understand those codes very well, and how he used it in daily conversation with various people. Other than that, based on the analysis, this part discusses the most dominant code until the least one spoken by the subject.

The most dominant code spoken by the subject based on the observation is the Kupangnese code. It was affected by the writer's existence through observation. That is why the subject switched to the Kupangnese code in most of his conversation. The example is in extract 1 below.

\section{Extract 1} were there]

The subject: "beta kalo ikut baru beta bagitu iiihhh" [I would feel iiihhh if I

Theo: "Elim ju kena bisik malam-malam, ais itu pintu le, tabuka tatutup sendiri pas malam" [Elim also heard whispers at night, and also the door, it was opened and closed by itself at night]

The subject: "No'o!" [Damn!]

It is quite interesting because the way the subject speaks and expresses his feelings is very similar to the people from Kupang. His tone, the placement of the pronoun beta (meaning ' $I$ ') in his utterance is similar to the people from Kupang when they are referring to themselves while telling and reacting to interesting stories, and his choices of words are similar with Kupangnese in common, such as the pronoun beta (means I) and the word bagitu to explain what the subject would have done if he was in that condition based on the story in the conversation. Other than that, his expression is very identical to the Kupangnese. As an example, when he expressed his feelings through the swear word in the Kupang dialect (No'o). It sounds natural and proves that he knows the function of the expression. Sometimes the expression is used by the Kupangnese to express emotions, insult someone, make a joke or praise someone.

\section{Extract 2}

The subject: "yang punya orang sini, ada cece cece, balom berkeluarga ju, masih muda" [The owner is from here, a young lady and has not married yet]

Theo: "pegawai dong banyak?" [are there lots of employees?]

The subject: "sonde, pegawai dong sonde terlalu banyak." [no, there are not too many employees]

In extract 2, it shows that the Kupang language is a casual language that has no formal form. The conversation happened in the office and the topic was about the employees in the office, but the subject kept responding with the Kupang dialect. The words balom and ju mean not yet and also. Both of them stand as adverbs in the subject's first utterance to describe that his boss has not married yet. Other than that, the words sonde means no or do not and dong means them. In its first and second appearances in the sentence, the word sonde stands as a negation. In the journal written by Jacob \& Grimes (2006), some negatives in the Kupang 
Fredrik: "Varieties of Code Used by a Mixed Culture Student"

dialect are widely used among the people, in extract 2 the word sonde is one of them and it stands as a standard negation 'no, not'.

The second code used is Papuan. Papuan code/dialect also has the formal and the informal form. The formal form of Papuan code is more like the Indonesian code; meanwhile, the informal code is the Papuan code/dialect that has been used widely among the people. Based on the analysis, the subject uses the formal Papuan code or Indonesian when he talked to someone that has no intimate relationship with him. It can be seen from the example below.

The subject: "Titan! macam 10 tahun tidak ketemu ee? Da, sampai ketemu."

[Titan! It has been like 10 years we have not met right? Bye, see you later]

The conversation happened when the subject wanted to say hi to his Papuan friend, but instead of using Papuan dialect tra, he chose to use the formal form tidak in the conversation. It was because Titan was not the subject's close friend.

On the other hand, when the subject was hanging out or joking with his friends from Papua in Papuan students' boarding house, he used the Papuan dialect. The example is in extract 3.

\section{Extract 3}

The subject: "sabar, ini sa su mandi kah belom e?" [wait, have I taken a shower or not?]

Aldo: "belom, lu belom mandi." [no, you have not]

The subject: "Andre tadi dia tra kesini kah?" [was Andre here before?]

Aldo: "Tra ada." [no, he was not]

The third code is Indonesian. There are two forms of Indonesian codes namely the standard form and the non-standard form. Based on the observation, the subject usually switches into the non-standard form of Indonesian on a particular occasion.

\section{Extract 4}

The subject: "nanti kalau ada yang mau diedisikan suruh transfer aja?" [if later there are things that they want to sell to us, just tell them to transfer?]

Supervisor: "ia suruh transfer aja, oh iya, tadi orang itu udah bayar kontribusinya ya" [yes, tell them to just transfer it, and that man has paid his contribution]

In extract 4, the subject used the word aja which is the non-standard Indonesian, and it makes the context of the conversation to be more casual when he talks to his supervisor.

\section{Extract 5}

Pengunjung: "Trus kalau kayak tas itu kan harus di ini (menunjukkan sesuatu) dulu kan" [So, if it is like the bag it has to be like this (showing something) first right] it]

The subject: "kayaknya ini per-orangan deh yang buat "[I think someone made

Pengunjung: "ia, soalnya itu nya persis banget sama kayak punya temanku." [yes, because it is very similar with my friend's]

The subject: "nanti kalau ada orang-nya saya kabarin mbak, mbak main-main ke sini, baik siap" [later if the person is here, I will contact you. You need to come here more often. Okay, got it]

Pengunjung: "makasih ya mas." [Thank you, mas] 
Other than that, the subject also used standard Indonesian when he served the customer while giving information. In extract 5 , he answered the customer politely and used the standard form of Indonesian, based on the Indonesian dictionary from KBBI.

Overall, based on the frequency between formal and informal forms of codes, the subject used informal code the most. It is very rare to see the subject speak in a formal code, except at a particular time when he served the customers in his office.

The fourth code is Javanese. There are levels in the Javanese code that have been explained in the introduction. The next extract explains the use of Javanese code by the subject.

\section{Extract 7}

The subject: "Njee, matursuwun nje." [okay, thank you] Tukang parkir: "nje." [okay]

Still, with the same position but in a different setting, he also used the ngoko level of Javanese when he talked to the parking officer in his office. Even though the parking officer was older, he used ngoko. It might be because he did not master the Javanese krama level.

The last code is English. For the English code, there are some English words the subject used in his conversation while. The subject also used the English words and it has the purposes, whether it is to express his feeling or give information. The frequency of the English code is more than three words. That is why the writer put the English code as one of the varieties codes in this study even though in most of the subject's conversation he did not have the intention to use English code.

\section{Extract 8}

MK: "belum, kalau dia itu setengah shift ke beta tu 100 kalau full 200. Ini kalau dia full, tapi dia tu biasa dia pagi, jam 11 sampai jam 4. Biasa dia full kalau misalnya beta ijin toh, beta kan masih part-time, dia kan full-time." [not yet, if he works half shift like me, he will get 100. If he works in full shift, he will get 200. If he works full shift, he usually takes the morning shift from 11 a.m. until 4 p.m. He usually works in full shift if I am absent. I am still a part-timer and he is a full-timer]

In the example above, even though the subject intention was to speak in Kupangnese he unconsciously switched into English code, by using some of the words. Most of the words in English such as shift, full, part-time, and full-time have the function for referential matters or in other ways to tell information.

\section{CONCLUSION}

Based on the findings, the writer found five codes/dialects in total spoken by the subject. The codes/dialects are Kupangnese, Papuan, Indonesian, Javanese, and English. Based on the observation and analysis, the writer found out that the subject was very fluent and mostly spoke in the Kupangnese dialect. The subject also spoke in Papuan dialect while he was in conversations with his friends from Papua. The least spoken code was English.

In conclusion, there were five codes/dialects found through this study and the most dominant codes/dialect was Kupangnese, because the observer participation affected the subject's choice of code. There are always options to use a particular code/dialect and through this research, the ability of using various codes has made the subject have a wide connection with others. 
Fredrik: "Varieties of Code Used by a Mixed Culture Student"

Hopefully, this study can motivate and prove the privilege of code-switching through its use in everyday life. For the future research related to this, the writer suggests that it is more interesting if the subjects are students from a particular language center so that the data can be more varied and diverse.

\section{REFERENCES}

Badan Pengembangan Bahasa dan Perbukuan, K. P. (2016). KBBI Daring. Retrieved from https://kbbi.kemdikbud.go.id/Beranda

Coulmas, F. (2005). Sociolinguistics the study of speakers' choices. New York: Cambridge University Press.

Hidayati, A. N. (2017). Penggunaan bahasa pertama (Bahasa Jawa) di dalam kelas anak usia 7 tahun pada siswa SDN Kateguhan Boyolali. Surabaya: Universitas Nahdlatul Ulama.

Holmes, J. (2013). An introduction to sociolinguistics (4th ed.). New York: Routledge.

Hornby, A. S. (2010). Oxford Advanced Learner's Dictionary (8th ed.). New York: Oxford University Press.

Jacob, J., \& Grimes, B. D. (2006). Developing a role for Kupang Malay: The contemporary politics of an eastern Indonesian creole. Kupang: Artha Wacana Press.

Kluge, A. (2017). A grammar of Papuan Malay. Berlin: Language Science Press.

Nardiati, S., Suwadji, Mp., S., Pardi, \& Suwatno, E. (1993). Kamus bahasa Jawa-Bahasa Indonesia I. Jakarta: Pusat Pembinaan dan Pengembangan Bahasa Departemen Pendidikan dan Kebudayaan.

Scott, Graham R., Hyun Kim, Ben E. W. Rumaropen, Eleonora L. Scott, Christian G. Nussy, Anita C. M. Yumbi \& Robert C. Cochran. 2008. Tong pu bahasa: A preliminary report on some linguistic and sociolinguistic features of Papuan Malay. Sentani: SIL International.

SOLO.co.id. (n.d.). Beberapa tingkatan Bahasa Jawa terima kasih. Retrieved from SOLO.co.id: https://solo.co.id/culture/bahasa-jawa/terimakasih 